\title{
IDENTIFICATION OF TRYPANOSOMA EVANSI BY DNA HYBRIDISATION USING A NON-RADIOACTIVE PROBE GENERATED BY ARBITRARY PRIMER PCR: SHORT COMMUNICATION
}

\author{
S. H. Basagoudanavar ${ }^{1}$, J. R. RaO ${ }^{2 *}$, Swati OMAnwar ${ }^{1}$, A. K. TIWARI ${ }^{1}$, R. K. Singh ${ }^{1}$, \\ R. S. KATARIA ${ }^{1}$ and G. BUTCHAIAH ${ }^{1}$ \\ ${ }^{1}$ National Biotechnology Centre; ${ }^{2}$ Division of Parasitology, Indian Veterinary Research \\ Institute, Izatnagar 243 122, India
}

(Received March 16, 2000; accepted October 30, 2000)

\begin{abstract}
A highly reproducible, dominant, monomorphic fragment of 473 base pair (bp) amplified from the genome of Trypanosoma evansi by arbitrary primer polymerase chain reaction (AP-PCR) was labelled with digoxigenin and investigated for its potential as DNA probe. Dot-blot hybridisation of total genomic DNA with the probe proved useful in detecting bubaline, cameline and equine strains of $T$. evansi down to $10 \mathrm{pg}$ of parasite template DNA. No cross-hybridisation was seen with Babesia bigemina, Theileria annulata and the bubaline host DNA. This probe may facilitate laboratory identification of $T$. evansi in developing countries, without the inherent risk associated with radioisotopes.
\end{abstract}

Key words: AP-PCR, Trypanosoma evansi, non-isotopic probe

Molecular techniques such as polymerase chain reaction (PCR), nucleic acid hybridisation and kDNA minicircle analysis are increasingly receiving attention for identification and characterisation of Trypanosoma evansi stocks (Masiga and Gibson, 1990; Waitumbi and Young, 1994; Zhang and Baltz, 1994; Wuyts et al., 1994, 1995; Paulo et al., 1998; Omanwar et al., 1999). Gene probes thus far described are based on identification of highly repetitive genomic sequences used as ${ }^{32} \mathrm{P}$-labelled probes. However, the use of radioactivity makes the methodology impractical for field use. The non-isotopic probes have great potential for use in developing countries as they are stable, not restricted by a short half-life and hazards associated with the radioactive probes.

The arbitrary primer - polymerase chain reaction (AP-PCR) technique has proved to be a powerful and rapid method for detecting polymorphic genetic markers in a number of organisms. Such markers can be used in phylogenetic studies, identification of parasite strains and species, and in comparison of field isolates. It requires little parasite material and is technically easy to perform. A

“Corresponding author; E-mail: jrrao@ivri.up.nic.in; Fax: +91 (581) 440584/4472841 
large number of anonymous markers can be readily obtained representing independent loci, which are not biased towards particular sequences and so representative of the genome (Carlton et al., 1995). In the present communication, we describe the molecular detection and identification of T. evansi using an AP-PCR derived monomorphic DNA marker as a probe.

Isolates of T. evansi of bubaline, cameline and equine origin were passaged in laboratory rodents giving short-term fulminating infections. Trypanosomes were then purified from the rodents' blood by diethylaminoethyl (DEAE) -cellulose chromatography using phosphate saline glucose, $\mathrm{pH} 8.0$ as elution buffer (Lanham and Godfrey, 1970). Total genomic DNA was extracted from the trypanosomes, as described by Sambrook et al. (1989).

A 473 bp monomorphic DNA fragment previously identified as strong reaction product by the primer $\mathrm{AP}_{12}$ (5'-TGCATCGTAC-3') in AP-PCR (Basagoudanavar et al., 1999) was isolated from the agarose gel using Genei Clean kit (Bangalore Genei, India). The DNA fragment was reamplified using the same amplification conditions described previously for AP-PCR (Basagoudanavar et al., 1999).

DNA labelling of the $473 \mathrm{bp}$ reamplified fragment was carried out by incorporation of digoxigenin-11-dUTP during PCR using DIG-DNA labelling by PCR and detection kit (Boehringer Mannheim, Germany) according to manufacturer's recommendations. The PCR reaction was conducted in $50 \mu \mathrm{l}$ volume containing $15 \mathrm{ng}$ DNA, $10 \mathrm{mM}$ Tris-HCl, $50 \mathrm{mM} \mathrm{KCl}, 1 \mathrm{mM} \mathrm{MgCl}$, PCR-DIG probe synthesis mix $(200 \mu \mathrm{M}$ each of dNTPs replacing the dTTP at $30 \%$ level with digoxigenin (DIG-dUTP), 15 pmol primer $\mathrm{AP}_{12}$ and 1.5 U Taq DNA polymerase. The amplification reaction was carried out in a Thermal Cycler (MJ Research, Watertown, MA, USA). Cycling conditions were the same as described previously (Basagoudanavar et al., 1999). The success of the labelling was confirmed by comparing the electrophoretic mobility of $3 \mu 1$ of labelled product in relation to unlabelled product on $1.4 \%$ agarose.

For blotting, the template DNA at various concentrations (1 pg to $25 \mathrm{ng}$ ) in $100 \mu \mathrm{l}$ of $0.1 \mathrm{mM}$ Tris-EDTA (pH 8.0) was boiled for $5 \mathrm{~min}$. To each dilution, $5 \mu l$ of $10 \mathrm{~N} \mathrm{NaOH}$ was added and incubated at room temperature for $10 \mathrm{~min}$. Then an equal volume $(105 \mu \mathrm{l})$ of $2 \mathrm{M}$ ammonium acetate was added and applied on to the Zeta probe GT (BioRad) membrane using minifold dot-blotting apparatus (BioRad). Similarly, for specificity assay, equal concentration (25 ng each) of genomic DNA of Trypanosoma evansi (bubaline strain), Babesia bigemina, Theileria annulata and bubaline host were blotted. The blots were dried and soaked in $2 \times \mathrm{SSC}$, and air dried before subjecting to UV cross-linking (120 $\mathrm{mJcm}^{-2}$ energy) for $5 \mathrm{~min}$, using an UV Cross linker (UVP, Upland, CA, USA).

After prehybridisation $\left(68^{\circ} \mathrm{C}, 3 \mathrm{~h}\right)$, hybridisation was carried out at $68^{\circ} \mathrm{C}$ overnight, in a hybridisation oven (Techne, Cambridge, UK) containing hybridi- 
sation buffer that included $25 \mu 1$ of freshly denatured DIG-labelled probe. Afterwards, the membranes were washed with $2 \times \mathrm{SSC}, 0.5 \%(\mathrm{w} / \mathrm{v}) \mathrm{SDS}$ at room temperature for $10 \mathrm{~min}$, followed by two more washing steps at $68{ }^{\circ} \mathrm{C}$ for $15 \mathrm{~min}$ each in $0.1 \% \mathrm{SSC}, 0.1 \%(\mathrm{w} / \mathrm{v}) \mathrm{SDS}$ under constant gentle agitation. The hybridised probe was immunodetected with anti-digoxigenin-AP conjugate $(1: 1000)$ in $1 \%$ blocking solution and visualised with the colorimetric substrate (NBT/Xphosphate in DMF).

Agarose gel electrophoresis of the reamplified AP-PCR product appeared as a single band of predicted $473 \mathrm{bp}$ size (Fig. 1A). This reamplified DNA fragment when used as DIG-labelled probe in a dot-blot hybridisation, showed a specific signal with $T$. evansi and no detectable signal against Babesia bigemina, Theileria annulata and bubaline host DNA (Fig. 1B). When purified DNA from T. evansi (buffalo isolate) was blotted in varying concentrations of $1 \mathrm{pg}, 10 \mathrm{pg}$, $100 \mathrm{pg}, 1 \mathrm{ng}, 10 \mathrm{ng}$ and $25 \mathrm{ng}$, signals of hybridisation were detected down to $10 \mathrm{pg}$ level. However, no detectable signal was seen with negative control (salmon sperm DNA) (Fig. 1C). The DNA templates of T. evansi strains originating from camel and horse also revealed similar sensitivity detection levels (data not shown).

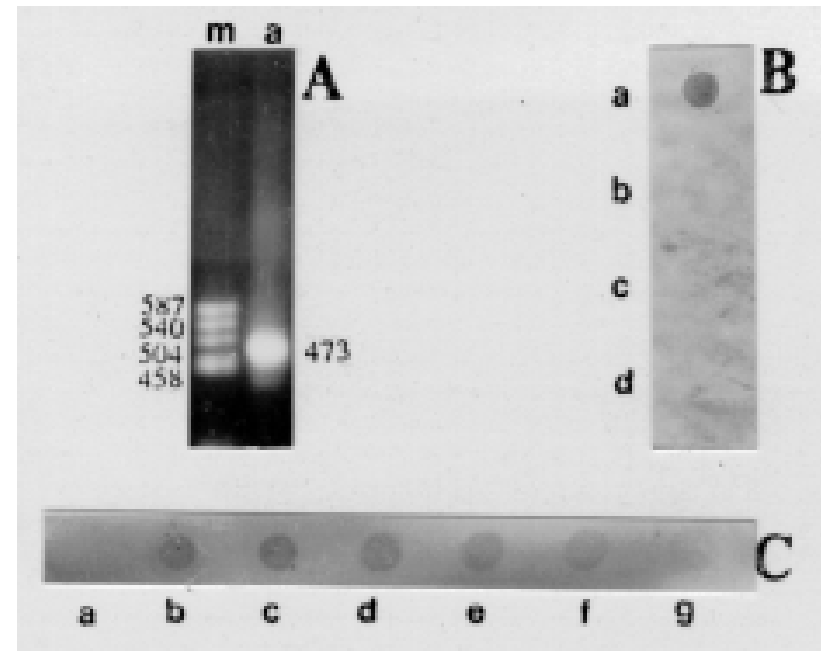

Fig. 1. A. Ethidium bromide stained agarose (1.4\%) gel showing reamplified AP-PCR product of T. evansi using primer $\mathrm{AP}_{12}$ (5'-TGCATCGTAC-3'). Lane a - reamplified product (473 bp fragment); $\mathrm{m}$ - DNA molecular weight marker pBR322 DNA/HaeIII digest. B. Specificity assay of AP-PCR generated $473 \mathrm{bp}$ DIG-labelled probe of $T$. evansi by dot-blot hybridisation: a to d indicate genomic DNA of T. evansi (a), B. bigemina (b), T. annulata (c), bubaline host DNA (d).

C. Sensitivity assay: a to $g$ indicate the concentration of DNA: $a-$ negative control; $b-25 \mathrm{ng}$; c - 10 ng; d - 1 ng; e - 100 pg; f - 10 pg; g - 1 pg 
The sensitivity of the nucleic acid based probes thus far reported ranged from 62 to $100 \mathrm{pg}$ of template DNA by Southern or dot-blot hybridisation (Masiga and Gibson, 1990; Viseshakul and Panyim, 1990; Zhang and Baltz, 1994). The development of DNA probes based on identification of repetitive elements, unique genes or spacer DNA sequences and cloning and/or de novo synthesis of the oligonucleotide sequences is time consuming. The advent of PCR for generation of RAPD using randomly chosen single oligonucleotide primers has simplified the identification of genetic markers for a number of parasites without the requirement of prior knowledge of their genomic nucleotide information (MacPherson and Gajadhar, 1994; Reddy et al., 1998). In the present study, a highly dominant DNA fragment common to three predominant buffalo, camel and horse isolates of $T$. evansi was used for the preparation of non-isotopic probe. Considering that $T$. evansi is a multi-host parasitising species, identification of a highly dominant DNA fragment common in isolates from various animal hosts is believed to lead to a possibility of application of this technique for sensitive identification of the organism.

Although the PCR assay earlier described (Omanwar et al., 1999) is more sensitive than the probe, the requirement of specialised and expensive equipment may be a limitation to have universal utility of the technique. The convenience of performing the hybridisation assay using the probe in a water bath at $68{ }^{\circ} \mathrm{C}$ as a substitute for hybridisation oven, while other steps are carried out at room temperature, makes this probing technique less expensive and relatively simple, allowing the unequivocal detection of Trypanosoma DNA. Yet another advantage of this non-isotopic probe is that it can be repeatedly used with proper storage and thus may be ideally suited for use in developing countries.

When used as hybridisation probe, the digoxigenin-labelled $473 \mathrm{bp}$ fragment was found to be of higher sensitivity than that of ${ }^{32} \mathrm{P}$-labelled probes earlier described using repetitive DNA sequences (Masiga and Gibson, 1990; Viseshakul and Panyim, 1990; Zhang and Baltz, 1994). As it gives no detectable crosshybridisation signal with $B$. bigemina and $T$. annulata, the two common haemoparasites and bubaline host DNA, this non-isotopic probe may facilitate laboratory identification of T. evansi in non-tsetse regions like India, without any of the inherent risks associated with radioisotopes.

\section{Acknowledgements}

The senior author thanks the Director, Indian Veterinary Research Institute (IVRI), Izatnagar for the award of Junior Research Fellowship and for the facilities provided for this work. Thanks are also due to Theileria and Babesia laboratories, IVRI for providing the Theileria and Babesia DNA samples. 


\section{References}

Basagoudanavar, S. H., Rao, J. R., Singh, R. K. and Butchaiah, G. (1999): Random amplification of polymorphic DNA fingerprinting of Trypanosoma evansi. Vet. Res. Commun. 23, 249-255.

Carlton, J. M. R., Howard, J., Jensen, J. B. and Walliker, D. (1995): A rapid technique for the detection of DNA polymorphisms in Plasmodium. Exp. Parasitol. 80, 163-166.

Lanham, S. M. and Godfrey, D. G. (1970): Isolation of salivarian trypanosomes from man and other animals using DEAE-cellulose. Exp. Parasitol. 28, 521-534.

MacPherson, J. M. and Gajadhar, A. A. (1994): Specific amplification of Sarcocystis cruzi DNA using a randomly primed polymerase chain reaction assay. Vet. Parasitol. 55, 267-277.

Masiga, D. K. and Gibson, W. C. (1990): Specific probes for Trypanosoma (Trypanozoon) evansi based on kinetoplast DNA minicircles. Mol. Biochem. Parasitol. 40, 279-284.

Omanwar, S., Rao, J. R., Basagoudanavar, S. H., Singh, R. K. and Butchaiah, G. (1999): Direct and sensitive detection of Trypanosoma evansi by polymerase chain reaction. Acta Vet. Hung. 47, 351-359.

Paulo, J. L., Pereira, de A., Momar, N., Bart, G. and Sabine, O. (1998): PCR primer evaluation for the detection of trypanosome DNA in naturally infected goats. Vet. Parasitol. 80, 111-116.

Reddy, Y. A., Rao, J. R., Butchaiah, G. and Sharma, B. (1998): Random amplified polymorphic DNA for the specific detection of bubaline Echinococcus granulosus by hybridisation assay. Vet. Parasitol. 79, 315-323.

Sambrook, J., Fritsch, E. F. and Maniatis, T. (1989): Molecular Cloning: A Laboratory Manual. Cold Spring Harbor Laboratory Press, Cold Spring Harbor, New York.

Viseshakul, N. and Panyim, S. (1990): Specific DNA probe for the sensitive detection of Trypanosoma evansi. Southeast Asian J. Trop. Med. Publ. Hlth. 21, 21-27.

Waitumbi, J. N. and Young, J. R. (1994): Electrophoretic karyotyping is a sensitive epidemiological tool for studying Trypanosoma evansi infections. Vet. Parasitol. 52, 47-56.

Wuyts, N., Chokesajjawattee, N. and Panyim, S. (1994): A simplified and highly sensitive detection of Trypanosoma evansi by DNA amplification. Southeast Asian J. Trop. Med. Publ. Hlth. 25, 266-271.

Wuyts, N., Chokesajjawattee, N., Sarataphan, N. and Panyim, S. (1995): PCR amplification of crude blood on microscope slides in the diagnosis of Trypanosoma evansi infection in dairy cattle. Ann. Belgian Soc. Trop. Med. 75, 229-237.

Zhang, Z. Q. and Baltz, T. (1994): Identification of T. evansi, T. equiperdum and T. brucei using repetitive DNA probes. Vet. Parasitol. 53, 197-208. 